\title{
Frequency of HPV in oral cavity squamous cell carcinoma
}

\author{
Priscila Marinho de Abreu', Anna Clara Gregório Có2, Pedro Leite Azevedo², Isabella Bittencourt do Valle', \\ Karine Gadioli de Oliveira ${ }^{3}$, Sônia Alves Gouvea ${ }^{3}$, Melissa Freitas Cordeiro-Silva ${ }^{4}$, lúri Drummond Louro', \\ José Roberto Vasconcelos de Podestá ${ }^{5}$, Jeferson Lenzi ${ }^{5}$, Agenor Sena ${ }^{5}$, Elismauro Francisco Mendonça ${ }^{6}$ \\ and Sandra Lúcia Ventorin von Zeidler ${ }^{1,2^{*}}$
}

\begin{abstract}
Background: The prevalence of high-risk human papillomavirus (HPV) DNA in cases of oral cavity squamous cell carcinoma (SCC) varies widely. The aim of this study is to investigate the frequency of high-risk HPV DNA in a large Brazilian cohort of patients with oral cavity SCC.

Methods: Biopsy and resected frozen and formalin-fixed paraffin-embedded specimens of oral cavity SCC were available from 101 patients who were recruited at two Brazilian centres. Stringent measures with respect to case selection and prevention of sample contamination were adopted to ensure reliability of the data. Nested PCR using MY09/MY11 and GP5 ${ }^{+} / \mathrm{GP}^{+}$as well as PGMY09/11 L1 consensus primers were performed to investigate the presence of HPV DNA in the tumours. HPV-positive cases were subjected to direct sequencing. Shapiro-Wilk and Student $t$ test were used to evaluate data normality and to compare the means, respectively. Qualitative variables were analysed by logistic regression.

Results: Our results demonstrate that the frequency of high-risk HPV types in oral cavity SCC is very low and is less than 4\%. All HPV-positive cases were HPV16. In addition, our results do not show a significant association between the tumour clinical features and the risk factors (tobacco, alcohol and HPV) for oral cavity SCC.

Conclusion: In the current study, we observed an overlapping pattern of risk factors that are related to tumour development. This, along with a low frequency of high-risk HPV DNA, supports the findings that HPV is not involved in the genesis of oral cavity SCC in Brazilian population.
\end{abstract}

Keywords: Oral cancer, HPV, Frequency, Incidence, Oral cavity, Squamous cell carcinoma, Human papillomavirus

\section{Background}

Head and neck squamous cell carcinoma (HNSCC) is a significant cause of cancer morbidity worldwide as 650,000 new cases and 350,000 deaths occur every year [1]. HNSCC encompasses tumours of the oral cavity, oropharynx, hypopharynx and larynx, which are each associated with different risk factors and prognoses. Latin America has a relatively high incidence of these tumours [1]. It was estimated that 15,290 new cases of oral cavity

\footnotetext{
* Correspondence: sandra.zeidler@ufes.br

${ }^{1}$ Programa de Pós-Graduação em Biotecnologia, Centro de Ciências da

Saúde, Universidade Federal do Espirito Santo, Vitoria, Espirito Santo, Brazil

2Departamento de Patologia, Programa de Pós-graduação em Biotecnologia,

Centro de Ciências da Saúde, Universidade Federal do Espirito Santo, Av.

Marechal Campos, 1468 Maruípe, Vitória, ES 29.040-090, Brazil

Full list of author information is available at the end of the article
}

squamous cell carcinoma (SCC) occurred in Brazil in 2015 [2]. The oral cavity is the most frequent site of cancer within the head and neck region and is in the "top ten" list of tumours with the highest incidences [1].

HNSCC is one of several cancers that is strongly associated with tobacco and alcohol use [3]. However, over the last 15 years, high-risk (HR) human papillomavirus (HPV) infection has also been aetiologically linked to a subset of HNSCCs. HPV involvement in oral and oropharyngeal carcinogenesis was first proposed by Syrjanen et al. in 1983 [4]. In 2007, the International Agency for Research on Cancer recognized human papillomavirus type 16 (HPV16) as the only carcinogenic type of HPV in sites other than the cervix uteri, including the anus, penis, vagina, vulva, oral cavity 
and oropharynx [5]. HPV16-associated carcinogenesis is mediated by expression of the viral E6 and E7 oncoproteins, which inactivate the tumour suppressor proteins p53 and retinoblastoma; this then disrupts cell cycle regulatory pathways [6]. Therefore, the lack of p53 mutations [7] and p16 protein accumulation [8-10], which occur as a result of the loss of transcriptional repression during early tumorigenesis, are considered to be hallmarks of HPV-related HNSCC [11].

Although the frequency of high-risk HPV that is detected may be higher in samples of HNSCC, substantial heterogeneity exists among studies in terms of the detection rates. A portion of this variation may be related to differences in the incidence among geographic locations and the head and neck subsites enrolled in the included studies [12]. Additionally, it is important to consider variations in the sample sources and the collection methods as well as in the HPV detection methods. Methods for the detection of HPV DNA include in situ hybridization and polymerase chain reaction (PCR), while methods for the detection of HPV E6/E7 RNA include quantitative reverse transcriptase PCR (qRT-PCR) and RNA in situ hybridization.

To support the involvement of HPV in head and neck tumours, few studies have been conducted to determine the frequency of HPV DNA exclusively in SCC of the oral cavity, specifically in Brazil $[13,14]$. Most of the published studies have included multiple subsites of HNSCC, which have precluded the specific analysis of HPV involvement in oral carcinogenesis [15]. Furthermore, the frequency of HPV infection in oral cavity SCC exhibits much variation among studies worldwide as well in different regions within Brazil [13, 14, 16].

The aim of this study is to investigate the frequency of high-risk HPV in a large Brazilian cohort of patients with oral cavity SCC. The relevance of this study lies in our accuracy of the selection of tumour sites and in the collection of samples. We also used different HPV DNA detection methods and adopted stringent measures to prevent sample contamination, which ensures the reliability of the data.

\section{Methods}

\section{Study subjects}

This is a multicentre cross-sectional study conducted at the following two Brazilian centres: Santa Rita de Cassia Hospital and University Hospital Antonio Cassiano de Moraes, which are both located in Espírito Santo. This study was approved by the clinical centre ethics committees and by the National Commission on Ethics in Research (Protocols 318/2011 and 681/2011). Written consent was given by each patient prior to his or her participation in the study.
A total of 171 cases of oral cavity SCC that were diagnosed by histopathology between 2012 and 2015 were reviewed. The inclusion criteria included tumours from oral cavity that were diagnosed according to the International Classification of Diseases, version 10 [17] and patients who had not undergone any previous antineoplastic treatment. The anatomical subsites selected were: tongue (C02.0, C02.3, C02.8, C02.9); gum and alveolar ridge (C03.0, C03.1, C03.9); floor of the mouth (C04.0, C04.1, C04.8, C04.9); palate (C05.0, C05.8, C05.9); buccal mucosa (C06.0, C06.1); retromolar trigone $(\mathrm{C} 06.2)$ and overlapping sites of other parts of mouth (C06.8, C06.9). Seventy cases were excluded for not presenting formalinfixed paraffin-embedded or frozen tissues available.

Following patient consent, 82 fresh tumour specimens were collected at the time of biopsy or surgical resection into RNAlater reagent (Qiagen, Valencia, CA, USA) and stored at $-80{ }^{\circ} \mathrm{C}$ until further processing. In addition, 19 formalin-fixed paraffin-embedded tumours were retrieved from the pathology archive at Santa Rita de Cassia Hospital.

Clinical and pathological data (i.e., age, gender, tumour site, TNM stage, alcohol consume and tobacco exposure) were obtained by interview and from the medical records. The clinical stage of the tumours was categorized as early (clinical stages I-II) or advanced clinical stages (clinical stages III-IV), and all tumours were classified according to the TNM classification system [18].

\section{DNA extraction and integrity}

Genomic DNA was obtained from frozen tissues and from four $10 \mu \mathrm{m}$-thick sections cut from the paraffin blocks. Formalin-fixed paraffin-embedded sections were placed in $2 \mathrm{ml}$ microcentrifuge tubes and dewaxed with multiple washes of xylene and graded solutions of $100 \%$, 95\% and 70\% ethanol. After overnight digestion with sodium dodecyl sulphate (SDS) and $5 \%$ of $20 \mathrm{mg} / \mathrm{ml}$ of $\mathrm{K}$ proteinase (Sigma, Saint Louis, USA) at $37^{\circ} \mathrm{C}$, DNA was extracted from both types of samples by standard phenol-chloroform-isoamylic alcohol and sodium acetate-ethanol precipitation. Rigorous efforts were made to avoid cross-contamination at every stage. A new microtome blade was used each time a new case was sectioned, and the components of the microtome were cleaned with xylene and ethanol after each sample was sectioned. In addition, aerosol tips were used for all pipetting steps, and separate rooms were used for preand post-PCR experimental steps.

DNA concentrations were estimated using a DyNA Quant 200 Fluorometer (Hoeffer Scientific, Holliston, MA, USA). To exclude false negative results derived from the degradation of DNA in samples that were overfixed, the integrity of the DNA was assessed by amplification of a fragment of the human $\beta$-globin gene using 
PCO3 (5'-ACACAACTGTGTTCACTAGC-3') and PCO7 (5'-GAAAACATCAAGGGTCCCAT-3') primers, which result in a 509-bp DNA fragment [19]. All $\beta$ globin-negative samples were excluded from further analysis.

\section{HPV DNA detection \\ Nested PCR using MY09/MY11 and $\mathrm{GP5}^{+} / \mathrm{GPG}^{+}$primers}

The detection of high-risk HPV was performed by nested PCR to amplify a part of the HPV L1 gene, which encodes the major capsid protein of several subtypes of HPV, as previously described by Jacob in 1995 [20]. Briefly, $50 \mathrm{ng}$ of DNA from each sample was amplified with the consensus primers MY09/MY11 followed by amplification with general primers $\mathrm{GP}^{+} / \mathrm{GP}^{+}$by twostep nested PCR. Standard PCR with the MY09/MY11 primers was performed as previously described [20,21]. Each sample was amplified with 50 pmol each of the primers MY09 (5'-CGTCCMARRGGAWACTGATC-3') and MY11 (5'-GCMCAGGGWCATAAYAATGG-3') in the presence of $6 \mathrm{mM} \mathrm{MgCl}_{2}$ buffer, $200 \mathrm{mmol}$ (each) dATP, dCTP, and dGTP, $600 \mathrm{mmol} \mathrm{dUTP,} \mathrm{and} 7.5 \mathrm{U}$ of Hot Start Taq DNA polymerase (Invitrogen, Waltham, MA, USA). Then, PCR was performed using the product of the first reaction as a template in $50 \mathrm{mM} \mathrm{KCl}, 10 \mathrm{mM}$ TrisHCl (pH 8.3), $200 \mathrm{mM}$ of each deoxynucleoside triphosphate, $3.5 \mathrm{mM} \mathrm{MgCl}$, $7.5 \mathrm{U}$ of Hot Start Taq DNA polymerase (Invitrogen, Waltham, MA, USA), and 50 pmol each of the GP5 $^{+}$(5'-TTTGTTACTGTGGT AGATACTAC-3') and GP6 $^{+}$(3'-CTTATACTAAATGT CAAATAAAAAG-5') primers. Amplifications were performed in a Mastercycler Nexus (Eppendorf, Hamburg, DE) with an activation at $94{ }^{\circ} \mathrm{C}$ for $7 \mathrm{~min}$ and 25 cycles (first step) or 15 cycles (second step) at $94{ }^{\circ} \mathrm{C}$ for $45 \mathrm{~s}, 56{ }^{\circ} \mathrm{C}$ (first step) or $46{ }^{\circ} \mathrm{C}$ (second step) for $45 \mathrm{~s}$ and $72{ }^{\circ} \mathrm{C}$ for $1 \mathrm{~min}$. This was followed by a final extension at $72{ }^{\circ} \mathrm{C}$ for $7 \mathrm{~min}$, and storage at $4{ }^{\circ} \mathrm{C}$.

\section{PGMY09/11 L1 consensus PCR}

Additionally, to ensure the reliability of the data, we subjected the samples to a second round of PCR using a consensus PGMY09/11 primer set. An equimolar mixture of each primer was added to the PCR master mix for a final concentration of 10 pmol of each oligonucleotide in the primer sets; the final $\mathrm{MgCl}_{2}$ concentration was $4 \mathrm{mM}$. Then, the PCR buffers, reagents, and amplification profiles were identical to those described by Gravitt in 2000 [21]. Cycling conditions were as follows: $95{ }^{\circ} \mathrm{C}$ for $5 \mathrm{~min}$, followed by 30 cycles at $95^{\circ} \mathrm{C}$ for $1 \mathrm{~min}, 57^{\circ} \mathrm{C}$ for $1 \mathrm{~min}, 72^{\circ} \mathrm{C}$ for $1 \mathrm{~min}$ and a 7 -min final extension period at $72{ }^{\circ} \mathrm{C}$ (Mastercycler Nexus, Eppendorf, Hamburg, DE).

Positive and negative controls were used for each amplification and consisted of a previously known HPVpositive cervical carcinoma and ultrapure water, respectively. The products were then subjected to electrophoresis on an $8 \%$ polyacrylamide gel followed by a silver stain. Specimens were considered positive for HPV DNA using the MY09/MY11 and $\mathrm{GP}^{+} / \mathrm{GP}^{+}$primer sets when they presented a 150-bp DNA fragment. This represents some of the low-risk genotypes $(6,11,40,42$, $43,44)$ or the high-risk genotypes $(16,18,31,33,35,39$, $45,51,52,56,58,59,66,68)$, as described by Jacobs (1995) [20]. Samples that were amplified using PGMY09/11 were considered HPV-positive if the PCR product was a 450-bp fragment. PGMY09/11 consensus primers allowed the detection of more than $30 \mathrm{HPV}$ genotypes as follows: $6,11,16,18,26,31,33,35,39,40,42$, $45,51,52,53,54,55,56,58,59,61,62,64,66,67,68$, 69, 70, 71, 72, 73, IS39, CP8304, CP6108, MM4, MM7, and MM8 [21].

\section{DNA sequencing}

PCR products were purified using the ExoSAP-IT PCR Clean-up Kit (GE Healthcare Life Sciences, Uppsala, SE) and were sequenced using the BigDye ${ }^{-}$Terminator v3. 1 Cycle Sequencing Kit (Applied Biosystems, Foster City, CA, USA). Capillary electrophoresis was performed in an ABI Prism 310 Genetic Analyzer (Applied Biosystems, Foster City, CA, USA). The sequences were analysed using the Basic Local Alignment Search Tool (BLAST) available online at National Center for Biotechnology Information (https://blast.ncbi.nlm.nih.gov/Blast. cgi).

\section{Statistical analysis}

Shapiro-Wilk test was used to evaluate data normality. Variables distribution were presented by mean, standard deviation. Student $t$ test was used to compare the mean of ages between HPV-positive and HPV-negative individuals. Multiple logistic regression was applied in order to compare HPV status, tumour size, and nodal involvement with risk factors. The level of significance adopted in all analysis was 5\% with a 95\% confidence interval. For the data analysis the Statistical Package for the Social Sciences, version 17 for Windows (SPSS, Chicago, USA) was used.

\section{Results}

DNA from all 19 formalin-fixed paraffin-embedded specimens produced a $\beta$-globin PCR 509-bp fragment, as did the majority of the frozen specimens (71 of 82 ; 85.6\%). DNA from 11 frozen biopsies which presented $\beta$-globin negative were excluded from the subsequent analysis. The reasons for the exclusion were the presence of degraded and low quality DNA from tiny fragments that could not be resubmitted to DNA extraction and the existence of PCR inhibitors. Thus, the HPV status was assessed in a total of 68 males and 22 females with a 
mean age at diagnosis of 57.9 years (range 30-93 years; standard deviation 12.2 years) and was reported as either positive or negative. The details concerning the clinical findings and the HPV status of the cases in our series are summarized in Table 1. Cases that exhibited HPVpositive status (3/90) were detected by nested PCR using the MY09/MY11 and $\mathrm{GP}^{+} / \mathrm{GP}^{+}$primer sets, and the frequency of HPV infection was found to be $3.3 \%$. Furthermore, $87 \mathrm{HPV}$-negative samples where enough DNA was present were also assessed by PGMY09/11; these samples presented a $100 \%$ concordance rate, which ensures the reliability of the previous results. The sequencing showed the presence of HPV16 in all HPVpositive cases originated from both formalin-fixed paraffin-embedded (1/19) and frozen tissues (2/71). No difference was observed considering the sample storage methods. Among the HPV-positive cases, two were heavy smokers and alcoholics males while the other was a female with no exposure to any of the known risk factors.

All HPV-positive cases were in advanced stage of the disease (III-IV) presenting tumour size (T3/T4) and lymph node metastasis $\left(\mathrm{N}^{+}\right)$at the time of diagnosis. Besides that, there was no significant association among HPV status and TNM stage as well as gender, alcohol consumption, tobacco use or tumour site (Table 1). The mean age of HPV-positive patients was 61.0 years, whereas the mean age of the HPV-negative patients was 57.5 years; this difference was not significant (Table 2). In addition, the most used prognostic factors tumour size and nodal involvement were not associated with alcohol consumption, tobacco use, or HPV infection. Therefore, these variables could not be considered risk or protection factors in our cohort (Tables 2 and 3).

\section{Discussion}

This study presented a cohort with a significant number of patients with oral cavity SCC. Our results demonstrate that the frequency of high-risk HPV types in oral cavity SCC is very low and is less than $4 \%$. We believe that this result is significant, as we have assessed a precise anatomical site in our cohort. We have thus avoided bias related to the differences in the incidence of oral SCC in other sites, especially in the oropharynx where the prevalence of high-risk HPV has been reported to be high $[22,23]$. Tumour sites were validated by verification of the database and the medical records; in the three HPV-positive cases, the tumours were located in the tongue and in the alveolar ridge (Table 1). In addition, rigorous efforts were taken to prevent sample contamination as previously described, which ensures the consistency of our results.

The reported prevalence of high-risk HPV DNA in oral cavity SCC varies widely. A large multicentre study

Table 1 Association of clinical findings and HPV status in oral cavity SCC $(n=90)$

\begin{tabular}{|c|c|c|c|c|c|c|c|}
\hline & \multicolumn{4}{|c|}{ HPV } & \multirow{3}{*}{$\begin{array}{l}\text { OR } \\
\text { (Adjusted) }\end{array}$} & \multirow[t]{3}{*}{$95 \% \mathrm{Cl}$} & \multirow{3}{*}{$\begin{array}{l}p- \\
\text { value }^{* *}\end{array}$} \\
\hline & \multicolumn{2}{|c|}{ Positive } & \multicolumn{2}{|c|}{ Negative } & & & \\
\hline & $\bar{n}$ & (\%) & $n$ & (\%) & & & \\
\hline \multicolumn{8}{|l|}{ Gender } \\
\hline Male & 2 & $(66.6)$ & 66 & $(75.9)$ & 1 & - & - \\
\hline Female & 1 & $(33.4)$ & 21 & $(24.1)$ & 3.023 & $(0.135-67.544)$ & 0.485 \\
\hline \multicolumn{8}{|l|}{ Tumour site } \\
\hline Tongue & 2 & $(66.7)$ & 47 & $(54.0)$ & $1,07 E+08$ & 0 & 0.988 \\
\hline Floor of the mouth & 0 & $(0.0)$ & 22 & $(25.3)$ & 1 & - & - \\
\hline Others ${ }^{\mathrm{a}}$ & 1 & (33.3) & 18 & $(20.7)$ & $2,07 E+08$ & 0 & 0.998 \\
\hline \multicolumn{8}{|l|}{ Alcohol Consumption } \\
\hline No & 1 & (33.3) & 37 & $(43.0)$ & 1 & - & - \\
\hline Yes & 2 & $(66.7)$ & 49 & $(57.0)$ & 2.446 & 0 & 0.637 \\
\hline \multicolumn{8}{|l|}{ Tobacco Consumption } \\
\hline No & 1 & (33.3) & 39 & $(45.3)$ & 1 & - & - \\
\hline Yes & 2 & $(66.7)$ & 47 & $(54.7)$ & 1.993 & $(0.045-88.793)$ & 0.722 \\
\hline \multicolumn{8}{|l|}{ TNM Stage } \\
\hline$|/| \mid$ & 0 & $(0.0)$ & 28 & $(32.9)$ & 1 & - & - \\
\hline III/IV & 3 & $(100.0)$ & 57 & $(67.1)$ & $1,30 E+08$ & 0 & 0.998 \\
\hline
\end{tabular}

Reference category of the dependent variable - HPV negative

OR Odds Ratio, Cl Confidence interval; **. Multiple logistic regression (Adjusted to all variables)

aPalate, retromolar trigone, gum, buccal mucosa, alveolar ridge

Data unknown: alcohol consumption - 1; tobacco consumption - 1; TNM stage - 2 
Table 2 Comparison of the ages of the patients with HPVpositive and HPV-negative oral cavity SCC

\begin{tabular}{llllll}
\hline HPV & $n$ & Mean & STD $^{b}$ & $C$ (95\%) & $p$ \\
\hline Negative & 87 & 57.5 & 12.0 & $54.91-60.09$ & $0.63^{a}$ \\
Positive & 3 & 61.0 & 16.0 & $46.00-79.00$ & \\
\hline
\end{tabular}

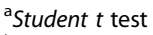

${ }^{\mathrm{b}}$ STD Standard deviation

reported HPV DNA in $4 \%$ of 766 oral cancers using the consensus PCR primers $\mathrm{GP}^{+} / \mathrm{GP}^{+}$[24]. Studies performed in United Kingdom and in the United States analysed large cohorts and found an HPV frequency of less than $2 \%$ and $5.6 \%$, respectively $[25,26]$. Moreover, in India, a study revealed an HPV infection rate of $46 \%$ in oral cavity SCC [27] while a meta-analysis published by Termine et al. (2008), in which 62 studies were analysed, revealed a $38.1 \%$ prevalence of HPV DNA in 4852 oral squamous cell carcinoma biopsy samples [28].

In Brazil, few studies have been conducted on the frequency of HPV in oral cavity SCC, and the data presented thus far are also discordant; data show a range of $0-19.2 \%$ frequency, which is mostly related to HPV16 infection [13, 16, 29]. Table 4 illustrates some of the consistent publications in recent years that have considered the frequency of HPV infection in oral cavity SCC.

Thus, to evaluate the involvement of HPV in the genesis of oral cavity SCC, the geographic distribution of the populations should be considered. Besides, the wide variation in HPV detection rates can be influenced by other factors, such as sensitivity of the HPV testing method, the coverage of HPV genotypes in the test panel, sample collection methods as well as sample storage conditions.

The most widely applied HPV detection methods are based on the PCR amplification of viral DNA. In the current study, we have used three different standard primer sets (MY09/MY11, GP5 ${ }^{+} / \mathrm{GP}^{+}$and PGMY09/11) and nested PCR to detect HPV DNA in head and neck tumours, which increases the sensitivity compared to a single PCR reaction [30]. Some advantages of the PCR methods used are the high sensitivity to detect more than 30 HPV genotypes, wide availability, and costeffectiveness [31]. A weakness of the standard PCRbased assay is that it can not distinguish oncogenic virus from biologically irrelevant virus because is not possible to identify integrated or episomal DNA [25, 28, 32]. In addition, PCR techniques have lower specificity compared with in situ hybridization and are technically troublesome to perform.

Although it is expected that HPV detection rate by PCR is usually higher in frozen tissues, in our study we did not find difference when we compared it to formalin-fixed paraffin-embedded tumours. Thus, we suggest that the use of nested PCR, which was adopted to avoid interference of small fragments from DNA degradation during fixation procedures could contribute to this result. In addition, other studies have used both clinical specimens and have not observed differences in HPV DNA detection rates using PCR-based methods [13, 25]. Furthermore, Lopes et al., (2011) [25] report that non-quantitative PCR methods, when subject to stringent quality control measures, such as the methodology adopted in our study, are effective methods to detect HPV DNA in those samples.

Studies have reported that patients with oral cavity SCC who do not present with a history of alcohol and tobacco consumption tend to be younger than patients who smoke and drink alcohol [16, 33]. Thus, the low frequency of HPV DNA in the present study might be related to the high mean age of our cohort, as no difference was observed between the mean age

Table 3 Association of prognostic features and the risk factors $(n=90)$

\begin{tabular}{|c|c|c|c|c|c|c|c|c|c|c|c|c|c|c|}
\hline & \multicolumn{4}{|c|}{ Tumour Size } & \multirow{3}{*}{$\begin{array}{l}\text { OR } \\
\text { (Adjusted) }\end{array}$} & \multirow[t]{3}{*}{$95 \% \mathrm{Cl}$} & \multirow{3}{*}{$\begin{array}{l}p- \\
\text { value }\end{array}$} & \multicolumn{4}{|c|}{ Nodal Involvement ${ }^{a}$} & \multirow{3}{*}{$\begin{array}{l}\text { OR } \\
\text { (Adjusted) }\end{array}$} & \multirow[t]{3}{*}{$95 \% \mathrm{Cl}$} & \multirow{3}{*}{$\begin{array}{l}p \text { - } \\
\text { value** }\end{array}$} \\
\hline & \multicolumn{2}{|c|}{$T 1 / T 2$} & \multicolumn{2}{|c|}{ T3/T4 } & & & & \multicolumn{2}{|l|}{ NO } & \multicolumn{2}{|l|}{$\mathrm{N+}$} & & & \\
\hline & $n$ & (\%) & $n$ & (\%) & & & & $n$ & (\%) & $n$ & (\%) & & & \\
\hline \multicolumn{15}{|l|}{ HPV status } \\
\hline Negative & 36 & $(100.0)$ & 48 & $(94.1)$ & 1 & - & - & 48 & $(100.0)$ & 36 & $(92.3)$ & 1 & - & - \\
\hline Positive & 0 & $(0.0)$ & 3 & (5.9) & $1.18 \mathrm{E}+09$ & 0 & 0.999 & 0 & $(0.0)$ & 3 & $(7.7)$ & $2.04 \mathrm{E}+09$ & 0 & 0.999 \\
\hline \multicolumn{15}{|c|}{ Alcohol Drinkers } \\
\hline No & 16 & $(44.4)$ & 21 & $(42.0)$ & 1 & - & - & 21 & $(44.7)$ & 16 & $(41.0)$ & 1 & - & - \\
\hline Yes & 20 & $(55.6)$ & 29 & $(58.0)$ & 0.708 & $(0.243-2.060)$ & 0.526 & 26 & $(55.3)$ & 23 & $(59.0)$ & 0.626 & $(0.209-1.180)$ & 0.404 \\
\hline \multicolumn{15}{|c|}{ Tobacco Users } \\
\hline No & 19 & $(52.8)$ & 19 & $(38.0)$ & 1 & - & - & 25 & $(53.2)$ & 13 & (33.3) & 1 & - & - \\
\hline Yes & 17 & $(47.2)$ & 31 & $(62.0)$ & 2173 & $(0.751-6.290)$ & 0.152 & 22 & $(46.8)$ & 26 & $(66.7)$ & 2947 & $(0.977-8.887)$ & 0.055 \\
\hline
\end{tabular}

Reference category of the dependent variable Tumor size - T1/T2; Reference category of the dependent variable Nodal Involvement- N0; OR Odds Ratio

Cl Confidence Interval; ${ }^{* *}$. Multiple logistic regression (Adjusted to all variables);

${ }^{\mathrm{a}} \mathrm{N} 0$ - absence of lymph node metastasis; $\mathrm{N}+-$ lymph node metastasis;

Data unknown: alcohol drinkers - 1; tobacco users - 1; tumour size - 3; nodal involvement - 3 
Table 4 Prevalence of HPV in oral cavity SCC

\begin{tabular}{|c|c|c|c|c|c|}
\hline Author / Year & Country & No. of cases & HPV (\%) & Samples & Methods \\
\hline Kaminagakura et al. [16] 2012 & Brazil & 114 & 19.2 & FFPE & $\mathrm{GP}^{+} / \mathrm{GP}^{+}$ \\
\hline Attner et al. [40] 2011 & Sweden & 87 & 78.0 & FFPE & $\mathrm{GP}^{+} / \mathrm{GP}^{+}$ \\
\hline Lopes et al. [25] 2011 & United Kingdom & 118 & $<2.0$ & $\mathrm{FT}^{\mathrm{b}} / \mathrm{FFPE}$ & $\mathrm{GP}^{+} / \mathrm{GP}^{+}$ \\
\hline Termine et al. [41] 2012 & Italy & 83 & 12.1 & FFPE & Nested PCR ${ }^{\mathrm{a}}$ PGMY09/11 \\
\hline Smith et al. [42] 2012 & USA & 170 & 9.4 & FFPE & $\mathrm{GP}^{+} / \mathrm{GP}^{+} \mathrm{PGMY09/11}^{-}$ \\
\hline Lee et al. [34] 2012 & Taiwan & 173 & 38.0 & FFPE & $\mathrm{MY} 11 / \mathrm{GP}^{+}$ \\
\hline Duray et al. [43] 2012 & Belgium & 147 & 44.2 & FFPE & $\mathrm{GP}^{+} / \mathrm{GP}^{+}$ \\
\hline Lingen et al. [26] 2013 & USA & 409 & 5.9 & FFPE & SPF10 \\
\hline González-Ramírez et al. [44] 2013 & Mexico & 80 & 5.0 & $\mathrm{FT}^{\mathrm{b}}$ & Nested PCR \\
\hline Lopez et al. [13] 2014 & Brazil & 121 & 6.6 & FT/FFPE & PGMY09/11 \\
\hline Chakrobarty et al. [27] 2014 & India & 83 & 46.0 & $\mathrm{FT}^{\mathrm{b}}$ & MY09/MY11 \\
\hline
\end{tabular}

${ }^{a}$ Nested PCR, MY09/11 and GP5 ${ }^{+} / \mathrm{GP}^{+}$

${ }^{\mathrm{b}} F T$ frozen tissue

of the individuals in the HPV-positive and HPVnegative groups. Moreover, most of our cases presented with an advanced stage of the disease and a history of long and intense exposure to known risk factors. Furthermore, no differences were observed among the anatomical subsites, tumour size, presence of lymph node metastasis and TNM stage among the HPV-positive and HPV-negative cases.

Furthermore, the frequency of HPV in our study is too close to the HPV DNA rates found in healthy individuals. The natural history of HPV infection has been extensively investigated in epidemiologic studies by PCRbased methods, HPV serology and DNA/RNA in situ hybridization [25, 34]. A review about epidemiological investigation on oral HPV prevalence in healthy individuals, published by Shigeishi \& Sugiyama (2016), reported that HPV frequency in saliva of healthy individuals have shown low and variable rates in a period of time, which is related to each patient's immune response and can, therefore, be inconstant. In addition, rates of oncogenic HPV infection in the oral cavity of healthy people are also known to be low (around 2\%) and the natural history of HPV in this anatomical site shows HPV acquisition is a rare event compared to genital or anal infections $[35,36]$.

Data from a database in the USA shows a reduction in tobacco use over the last several decades [37]. Although HNSCC is closely linked to tobacco and alcohol use, its increasing incidence indicates that HPV16-related HNSCC arises in the oropharynx [24, 33, 38]. In contrast, the incidence of oral cavity SCC has declined significantly between 1973 and 2004 at a yearly rate of 1 . $85 \%$ [39], which suggests that HPV is not related to oral carcinogenesis. These results are reinforced by the variation in the frequency of HPV DNA, as demonstrated in this work and in other studies [40-44].

\section{Conclusion}

In conclusion, in the current study, we observed an overlapping pattern of the risk factors tobacco and alcohol; this along with the low frequency of HPV DNA, supports the evidence that HPV is not involved in the development of oral cavity SCC in Brazilian population.

\section{Abbreviations}

HNSCC: Head and Neck Squamous Cell Carcinoma; HPV: Human Papillomavirus; HPV16: Human Papillomavirus type 16; HR: High Risk; PCR: Polymerase Chain Reaction; qRT-PCR: Quantitative Reverse TranscriptasePCR; SCC: Squamous Cell Carcinoma; SDS: Sodium dodecyl sulphate

\section{Acknowledgements}

We thank the Laboratório Multiusuário de Análises Biomoleculares (LABIOM UFES) and Professor Liliana Cruz Spano for all support on HR-HPV PCR.

\section{Funding}

This work was supported by Fundação de Amparo à Pesquisa do Estado do Espírito Santo (FAPES award number 60929073/2013) and Coordenação de Aperfeiçoamento de Pessoal de Nível Superior (Bolsista CAPES - Proc. $n^{\circ}$ 11780/13-4).

\section{Availability of data and materials}

The datasets supporting the conclusions of this article are included within the article and its supplementary information files.

\section{Authors' contributions}

SZ and PMA conceived and conduced study design as well draft the manuscript. AC, IV and PLA carried out all laboratory experiments and cooperate to draft the manuscript. AS, JL, EM and JP conduced patient recruitment, supplied all samples, and had a revising critically the manuscript. SG and KO assisted on data quality control, statistical analysis and critical revision of the manuscript. MS and IL participated in data acquisition and critical revision of the manuscript. All authors read and approved the final manuscript and agreed to be accountable for all aspects of the work

\section{Ethics approval and consent to participate}

This study was approved by the ethics committee of CIAS (Centro Integrado de Atenção a Saúde) - Unimed Vitória (Protocol 318/2011) and by the National Commission on Ethics in Research (Protocol 681/2011). All patients gave written informed consent for this study.

Consent for publication

Not applicable. 


\section{Competing interests}

The authors declare that they have no competing interests.

\section{Publisher's Note}

Springer Nature remains neutral with regard to jurisdictional claims in published maps and institutional affiliations.

\section{Author details}

${ }^{1}$ Programa de Pós-Graduação em Biotecnologia, Centro de Ciências da Saúde, Universidade Federal do Espirito Santo, Vitoria, Espirito Santo, Brazil. 2Departamento de Patologia, Programa de Pós-graduação em Biotecnologia, Centro de Ciências da Saúde, Universidade Federal do Espirito Santo, Av. Marechal Campos, 1468 Maruípe, Vitória, ES 29.040-090, Brazil. ${ }^{3}$ Departamento de Ciências Fisiológicas, Centro de Ciências da Saúde, Universidade Federal do Espirito Santo, Vitoria, Espirito Santo, Brazil. ${ }^{4}$ Faculdade Católica Salesiana do Espírito Santo, Vitória, Espírito Santo, Brazil. ${ }^{5}$ Programa de Prevenção e Detecção Precoce do Câncer Bucal, Setor de Cirurgia de Cabeça e Pescoço, Hospital Santa Rita de Cássia, Vitória, Espírito Santo, Brazil. ${ }^{6}$ Faculdade de Odontologia, Universidade Federal de Goiás, Goiânia, Goiás, Brazil.

\section{Received: 19 July 2016 Accepted: 19 March 2018}

\section{Published online: 27 March 2018}

\section{References}

1. Ferlay J, Soerjomataram I, Dikshit R, Eser S, Mathers C, Rebelo M, Parkin DM, Forman D, Bray F. Cancer incidence and mortality worldwide: sources, methods and major patterns in GLOBOCAN 2012. Int J Cancer. 2015;136: E359-86.

2. Ministério da Saúde, INCA. Estimativa 2014: Incidência de Câncer no Brasil. Rio de Janeiro: INCA. p. 2014

3. Leemans $\mathrm{CR}$, Braakhuis BJM, Brakenhoff RH. The molecular biology of head and neck cancer. Nat Rev Cancer. 2011;11:9-22.

4. Syrjanen KJ, Pyrhonen S, Syrjanen SM, Lamberg MA. Immunohistochemical demonstration of human papilloma virus (HPV) antigens in oral squamous cell lesions. Br J Oral Surg. 1983:21:147-53.

5. IARC. IARC monographs on the evaluation of carcinogenic risks to humans. $\checkmark$ 90. França: IARC; 2007

6. Chaudhary AK, Singh M, Sundaram S, Mehrotra R. Role of human papillomavirus and its detection in potentially malignant and malignant head and neck lesions: updated review. Head Neck Oncol. 2009;1(1):22.

7. Westra WH, Taube JM, Poeta ML, Begum S, Sidransky D, Koch WM. Inverse relationship between human papillomavirus-16 infection and disruptive p53 gene mutations in squamous cell carcinoma of the head and neck. Clin Cancer Res. 2008;14:366-9.

8. Kumar B, Cordell KG, Lee JS, Worden FP, Prince ME, Tran HH, Wolf GT, Urba SG, Chepeha DB, Teknos TN, Tsien Cl, Taylor JMG, Silva NJD, Yang K, Kurnit MD, Bauer JA, Bradford CR, Carey TE. EGFR, p16, HPV titer, BCl-XL and p53, sex, and smoking as indicators of response to therapy and survival in oropharyngeal cancer. Clin Oncol. 2008;26:3128-37.

9. O'Regan EM, Toner ME, Finn SP, Fan CY, Ring M, Hagmar B, Timon C, Smyth $P$, Cahill S, Flavin R, Sheils OM, O'Leary JJ. p16INK4A genetic and epigenetic profiles differ in relation to age and site in head and neck squamous cell carcinomas. Hum Pathol. 2008:39:452-8.

10. Weinberger PM, Yu Z, Haffty BG, Kowalski D, Harigopal M, Brandsma J, Sasaki C, Joe J, Camp RL, Rimm DL, Psyrri A. Molecular classification identifies a subset of human papillomavirus - associated oropharyngeal cancers with favorable prognosis. J Clin Oncol. 2006:24:736-47.

11. Mroz EA, Baird AH, Michaud WA, Rocco JW. $\mathrm{COOH}$-terminal binding protein regulates expression of the p16INK4A tumor suppressor and senescence in primary human cells. Cancer Res. 2008;68:6049-53.

12. Kreimer AR, Clifford GM, Boyle P, Franceschi S. Human papillomavirus types in head and neck squamous cell carcinomas worldwide: a systematic review. Cancer Epidemiol Biomark Prev. 2005;14:467-75.

13. López RVM, Levi JE, Eluf-Neto J, Koifman RJ, Koifman S, Curado MP, Michaluart-Junior P, Figueiredo DLA, Saggioro FP, de Carvalho MB, Kowalski LP, Abrahão M, de Góis-Filho F, Tajara EH, Waterboer T, Boffetta P, Brennan P, Wünsch-Filho V. Human papillomavirus (HPV) 16 and the prognosis of head and neck cancer in a geographical region with a low prevalence of HPV infection. Cancer Causes Control. 2014;25:461-71.
14. Soares RC, Oliveira MC, Souza LB, Costa AL, Medeiros SRB, Pinto LP. Human papillomavirus in oral squamous cells carcinoma in a population of 75 Brazilian patients. Am J Otolaryngol. 2007;28:397-400.

15. Paolini F, Rizzo C, Sperduti I, Pichi B, Mafera B, Rahimi SS, Vigili MG, Venuti A. Both mucosal and cutaneous papillomaviruses are in the oral cavity but only alpha genus seems to be associated with cancer. J Clin Virol. 2013;56:72-6.

16. Kaminagakura E, Villa LL, Andreoli MA, Sobrinho JS, Vartanian JG, Soares FA, Nishimoto IN, Rocha R, Kowalski LP. High-risk human papillomavirus in oral squamous cell carcinoma of young patients. Int J Cancer. 2012;130:1726-32.

17. World Health Organization. International Statistical Classification of Diseases and Related Health Problems. Tenth Revision. 2nd ed. v 2. Geneva: WHO; 2004.

18. Sobin LH, Gospodarowicz MK, Wittekind C. TNM: Classification of mMalignant Tumours. 7th ed. Oxford: Wiley-Blackwell; 2009.

19. Husman ADR, Snijders PJF, Stell HV, Brulel AJC Van De, Meijer C. Processing of long-stored archival cervical smears for human papillomavirus detection by the polymerase chain reaction. Br J Cancer. 1995; 72:412-417.

20. Jacobs MV, De Roda Husman AM, Van den Brule AJC, Snijders PJF, Meijer CJLM, Walboomers JMM. Group-specific differentiation between high- and low-risk human papillomavirus genotypes by general primer-mediated PCR and two cocktails of oligonucleotide probes. J Clin Microbiol. 1995;33:901-5.

21. Gravitt PE, Peyton CL, Alessi TQ, Wheeler CM, Coutlée F, Hildesheim A, Schiffman MH, Scott DR, Apple RJ. Improved amplification of genital human papillomaviruses. J Clin Microbiol. 2000:38:357-61.

22. Machado J, Reis PP, Zhang T, Simpson C, Xu W, Perez-Ordonez B, Goldstein DP, Brown DH, Gilbert RW, Gullane PJ, Irish JC, Kamel-Reid S. Low prevalence of human papillomavirus in oral cavity carcinomas. Head Neck Oncol. 2010;2(1):6

23. St Guily JL, Jacquard AC, Prétet $J$, Haesebaert J, Beby-Defaux A, Clavel C, Agius $G$, Birembaut $P$, Okaïs $C$, Léocmach $Y$, Soubeyrand $B$, Pradat $P$, Riethmuller D, Mougin C, Denis F. Human papillomavirus genotype distribution in oropharynx and oral cavity cancer in France-the EDiTH VI study. J Clin Virol. 2011:51:100-4.

24. Herrero R, Castellsagué X, Pawlita M, Lissowska J, Kee F, Balaram P, Rajkumar $T$, Sridhar $H$, Rose B, Pintos J, Fernández L, Idris A, Sánchez MJ, Neto A, Talamini R, Tavani A, Bosch FX, Reidel U, Snijders PJF, Meijer CJLM, Viscidi R, Muñoz N, Franceschi S. Human papillomavirus and oral Cancer: the International Agency for Research on Cancer multicenter study. J Natl Cancer Inst. 2003:95:1772-83.

25. Lopes V, Murray P, Williams H, Woodman C, Watkinson J, Robinson M Squamous cell carcinoma of the oral cavity rarely harbours oncogenic human papillomavirus. Oral Oncol. 2011;47:698-701.

26. Lingen MW, Xiao W, Schmitt A, Jiang B, Pickard R, Kreinbrink P, PerezOrdonez B, Jordan RC, Gillison ML. Low etiologic fraction for high-risk human papillomavirus in oral cavity squamous cell carcinomas. Oral Oncol. 2013:49:1-8.

27. Chakrobarty B, Roy JG, Majumdar S, Uppala D. Relationship among tobacco habits, human papilloma virus (HPV) infection, p53 polymorphism/mutation and the risk of oral squamous cell carcinoma. J Oral Maxillofac Pathol. 2014; 18:211-6.

28. Termine N, Panzarella V, Falaschini S, Russo A, Matranga D, Lo Muzio L, Campisi G. HPV in oral squamous cell carcinoma vs head and neck squamous cell carcinoma biopsies: a meta-analysis (1988-2007). Ann Oncol. 2008:19:1681-90.

29. Spíndula-Filho JV, Cruz AD, Oton-Leite AF, Batista AC, Leles CR, Alencar R de CG, Saddi VA, Mendonça EF. Oral squamous cell carcinoma versus oral verrucous carcinoma: an approach to cellular proliferation and negative relation to human papillomavirus (HPV). Tumor Biol. 2011;32:409-16.

30. Fuessel Haws AL, He Q, Rady PL, Zhang L, Grady J, Hughes TK, Stisser K, Konig R, Tyring SK. Nested PCR with the PGMY09/11 and GP5 +/6 + primer sets improves detection of HPV DNA in cervical samples. J Virol Methods. 2004;122:87-93.

31. Cantley RL, Gabrielli E, Montebelli F, Cimbaluk D, Gattuso P, Petruzzelli G. Ancillary studies in determining human papillomavirus status of squamous cell carcinoma of the oropharynx: a review. Patholog Res Int. 2011;2011:1-7.

32. Dayyani F, Etzel CJ, Liu M, Ho C-H, Lippman SM, Tsao AS. Meta-analysis of the impact of human papillomavirus (HPV) on cancer risk and overall survival in head and neck squamous cell carcinomas (HNSCC). Head Neck Oncol. 2010;2:1-11.

33. Marur S, Souza GD, Westra WH, Forastiere AA. HPV-associated head and neck cancer : a virus-related cancer epidemic. Lancet Oncol. 2010;11:781-9. 
34. Lee LA, Huang CG, Liao CT, Lee LY, Hsueh C, Chen TC, Lin CY, Fan KH, Wang HM, Huang SF, Chen IH, Kang CJ, Ng SH, Yang SL, Tsao KC, Chang YL, Yen TC. Human papillomavirus-16 infection in advanced oral cavity cancer patients is related to an increased risk of distant metastases and poor survival. PLoS One. 2012;7:7-9.

35. Kreimer AR, Pierce Campbell CM, Lin H-Y, Fulp W, Papenfuss MR, Abrahamsen M, Hildesheim A, Villa LL, Salmerón JJ, Lazcano-Ponce E, Giuliano AR. Incidence and clearance of oral human papillomavirus infection in men: the HIM cohort study. Lancet. 2013;382:877-87.

36. Shigeishi $H$, Sugiyama M. Risk factors for oral human papillomavirus infection in healthy individuals: a systematic review and meta-analysis. J Clin Med Res. 2016;8:721-9.

37. Chaturvedi AK, Engels EA, Pfeiffer RM, Hernandez BY, Xiao W, Kim E, Jiang B, Goodman MT, Sibug-Saber M, Cozen W, Liu L, Lynch CF, Wentzensen N, Jordan RC, Altekruse S, Anderson WF, Rosenberg PS, Gillison ML. Human papillomavirus and rising oropharyngeal cancer incidence in the United States. J Clin Oncol. 2011:29:4294-301.

38. Smith EM, Ritchie JM, Summersgill KF, Klussmann JP, Lee JH, Wang D, Haugen TH, Turek LP. Age, sexual behavior and human papillomavirus infection in oral cavity and oropharyngeal cancers. Int J Cancer. 2004;108:766-72.

39. Chaturvedi AK, Engels EA, Anderson WF, Gillison ML. Incidence trends for human papillomavirus-related and -unrelated oral squamous cell carcinomas in the United States. J Clin Oncol. 2008;26:612-9.

40. Attner P, Du J, Näsman A, Hammarstedt L, Ramqvist T, Lindholm J, Marklund L, Dalianis T, Munck-Wikland E. Human papillomavirus and survival in patients with base of tongue cancer. Int J Cancer. 2011;128:2892-7.

41. Termine N, Giovannelli L, Rodolico V, Matranga D, Pannone G, Campisi G. Biopsy vs. brushing: comparison of two sampling methods for the detection of HPV DNA in squamous cell carcinoma of the oral cavity. Oral Oncol. 2012;48:870-5.

42. Smith EM, Rubenstein LM, Haugen TH, Pawlita M, Turek LP. Complex etiology underlies risk and survival in head and neck cancer human papillomavirus, tobacco, and alcohol: a case for multifactor disease. J Oncol. 2012;2012:1-9.

43. Duray A, Descamps G, Decaestecker C, Remmelink M, Sirtaine N, Lechien J, Ernoux-Neufcoeur P, Bletard N, Somja J, Depuydt CE, Delvenne P, Saussez S. Human papillomavirus DNA strongly correlates with a poorer prognosis in oral cavity carcinoma. Laryngoscope. 2012;122:1558-65.

44. González-Ramírez I, Irigoyen-Camacho ME, Ramírez-Amador V, LizanoSoberón M, Carrillo-García A, García-Carrancá A, Sánchez-Pérez Y, MéndezMartínez R, Granados-García M, Ruíz-Godoy LM, García-Cuellar CM. Association between age and high-risk human papilloma virus in Mexican oral cancer patients. Oral Dis. 2013;19:796-804

\section{Submit your next manuscript to BioMed Central and we will help you at every step:}

- We accept pre-submission inquiries

- Our selector tool helps you to find the most relevant journal

- We provide round the clock customer support

- Convenient online submission

- Thorough peer review

- Inclusion in PubMed and all major indexing services

- Maximum visibility for your research

Submit your manuscript at www.biomedcentral.com/submit

CBiomed Central 